International Journal of Physical Sciences and Engineering
Available online at http://sciencescholar.us/journal/index.php/ijpse
Vol. 2 No. 2, August 2018, pages: $111 \sim 119$
e-ISSN : 2550-6943, p-ISSN : 2550-6951
https://doi.org/10.29332/ijpse.v2n2.169

\title{
The Concentration of Radon Gas in Air-Conditioned Indoor: Air Quality Can Increase the Potential of Lung Cancer
}

\begin{tabular}{|c|c|}
\hline \multicolumn{2}{|c|}{$\begin{array}{l}\text { I Gusti Agung Ayu Ratnawati a , Gusti Ngurah Sutapa b }{ }^{\text {, Ni Nyoman Ratini c }} \\
\text { tory: Received } 10 \text { March 2018, Accepted in revised form } 10 \text { July 2018, Approved } 17 \text { August 2018, } \\
\text { Available online } 21 \text { August } 2018\end{array}$} \\
\hline Correspondence Author a & Abstract \\
\hline $\begin{array}{l}\text { Keywords } \\
\text { Air quality; } \\
\text { Air-conditioned room; } \\
\text { Gypsum; } \\
\text { Lung cancer; } \\
\text { Radon gas radiation; }\end{array}$ & $\begin{array}{l}\text { Research has been conducted on the concentration of radon gas in air quality in } \\
\text { air-conditioned rooms that can increase the potential for lung cancer. Indoor } \\
\text { air quality is influenced by factors such as room occupants, material buildings, } \\
\text { equipment and furniture in the room, contamination of pollutants from the } \\
\text { outdoor air, seasonal influences, lighting, temperature, humidity, indoor noise, } \\
\text { and ventilation. In addition, indoor air quality can be affected by radon gas. The } \\
\text { concentration of radon gas is relatively high compared to other natural } \\
\text { radionuclides. It is estimated that around } 55 \% \text { of the radionuclide } \\
\text { concentration in nature comes from radon gas and is the largest source of } \\
\text { radiation received by the world population, which is around } 1.3 \text { mSv/year. } \\
\text { Based on the Risert of the National Institute of Occupational Health and Safety } \\
\text { (NIOSH), America in } 1997 \text { as many as } 52 \% \text { of respiratory diseases associated } \\
\text { with sick building syndrome stemmed from a lack of ventilation in the room } \\
\text { and poor AC room performance, thus increasing the potential for lung cancer. } \\
\text { The method used in this study is to determine the physical quantity and } \\
\text { concentration of the radiation dose of radon gas in the room. The results show } \\
\text { that air quality in terms of temperature, humidity, and noise is significantly still } \\
\text { in compliance with environmental health requirements according to } \\
\text { Kepmenkes No. } 1405 / M e n k e s / S K / X I / 2002 \text {. But the lighting in the room has } \\
\text { not been significantly fulfilled. Rooms with gypsum ceilings increase radiation } \\
\text { doses and air-conditioned rooms can accumulate radiation doses evenly in the } \\
\text { room. }\end{array}$ \\
\hline
\end{tabular}

e-ISSN: 2550-6943, p-ISSN: 2550-6951 ๑Copyright 2018. The Author. SS Journals Published by Universidad Técnica de Manabí. This is an open-access article under the CC BY-SA 4.0 license (https://creativecommons.org/licenses/by-sa/4.0/) All rights reserved.

a Physics of Udayana University Bali, Indonesia

b Physics of Udayana University Bali, Indonesia

c Physics of Udayana University Bali, Indonesia 


\section{Contents}

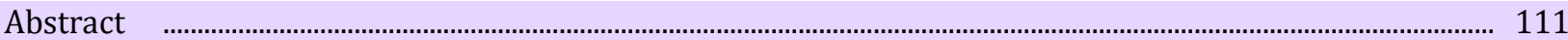

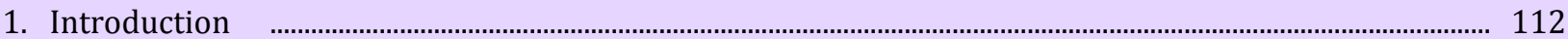

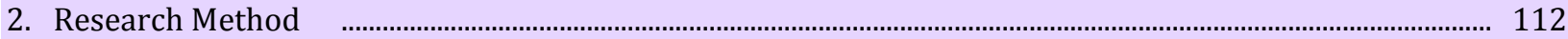

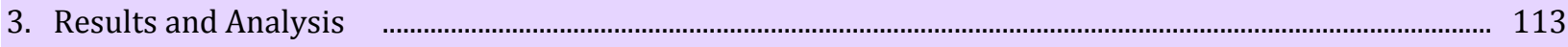

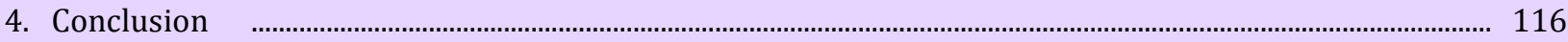

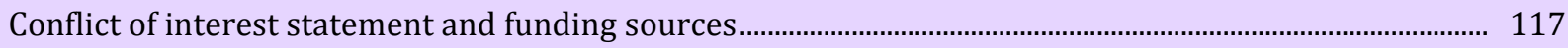

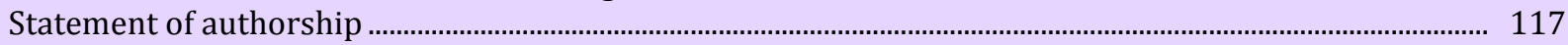

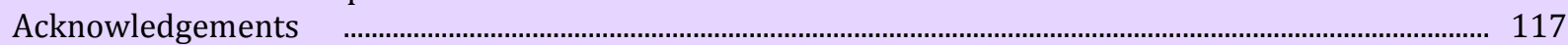

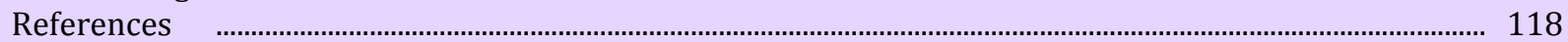

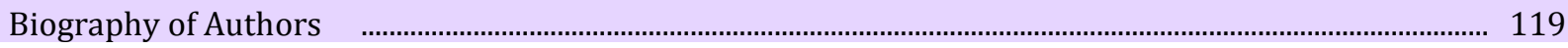

\section{Introduction}

Radon gas (222Rn) is one of the noble gas that is radioactive, colorless, odorless, invisible, and cannot be felt so that it cannot be detected by the senses. This radionuclide is a primordial natural radionuclide, the product of the radium (226Ra) son of the uranium series (238U) found in the earth's crust [1]. Radon gas is released from the earth's surface into the air continuously, moving freely and into the house by diffusion through the pores of the soil, building materials, and water. Indoor air quality can be affected by radon gas. The concentration of radon gas is relatively high compared to other natural radionuclides. It is estimated that around 55\% of the radionuclide concentration in nature comes from radon gas and is the largest source of radiation received by the world population, which is around $1.3 \mathrm{mSv} /$ year $[2,3]$.

Indoor air quality or indoor air quality is one aspect to scientists who focus on air quality or quality in a room that will be inserted into a room or building occupied by humans. Factors that influence air quality in the room are the activities of the occupants of the room, building material, equipment and indoor furniture, contamination of pollutants from the outdoor air, seasonal influences, lighting, indoor air temperature and humidity, and ventilation. Based on the Risert of the National Institute of Occupational Health and Safety (NIOSH), America in 1997 as many as $52 \%$ of respiratory diseases associated with sick building syndrome stemmed from the lack of ventilation in the room and poor AC room performance [4,5]. According to Sudarman (2003), the highest radon concentration is found in the bedroom (room) that uses air conditioning and has the potential to increase lung cancer. Based on the latest analysis to estimate lung cancer risk from long-term (chronic) radon exposure in the room (home), a relative risk value (RR) is needed. The RR value is calculated based on the model made from epidemiological-cohort study data for low radon exposure $(<50$ WLM) throughout work. In accordance with the RR model, a special committee in the field of Epidemiology UNSCEAR states that there is a linear correlation between the chances of lung cancer risk and exposure to radon in the room. Estimated RR value of chronic lung cancer (clc) is $2.5 \times 104 \mathrm{clc} / \mathrm{WLM}$, this value is higher than BEIR IV report of $2.24 \times 104 \mathrm{clc} /$ WLM and lowers according to ICIRP 65 estimates of $2.80 \times 104 \mathrm{clc} / \mathrm{WLM}$ $[6,10]$.

\section{Research Method}

\section{Research procedure}

The implementation of the research took five measurement points which were conditioned as points X1, $\mathrm{X} 2, \mathrm{X} 3, \mathrm{X} 4$, and $\mathrm{X} 5$. Where points $\mathrm{X} 1, \mathrm{X} 2, \mathrm{X} 3$, and $\mathrm{X} 5$ are each placed in each corner of the room, while X3 is placed in the middle of the room. Measurements were made on four different rooms where room I was a room with a non-AC non-gypsum ceiling, room II was a room with an air-conditioned non-gypsum ceiling, room III was a room with a non-gypsum ceiling Air conditioning and room IV are rooms with air-conditioned gypsum ceilings. 
Research Block Diagram

The research scheme conducted to facilitate the research process starts from the ceiling making process and radiation measurements are described in Figure 1.

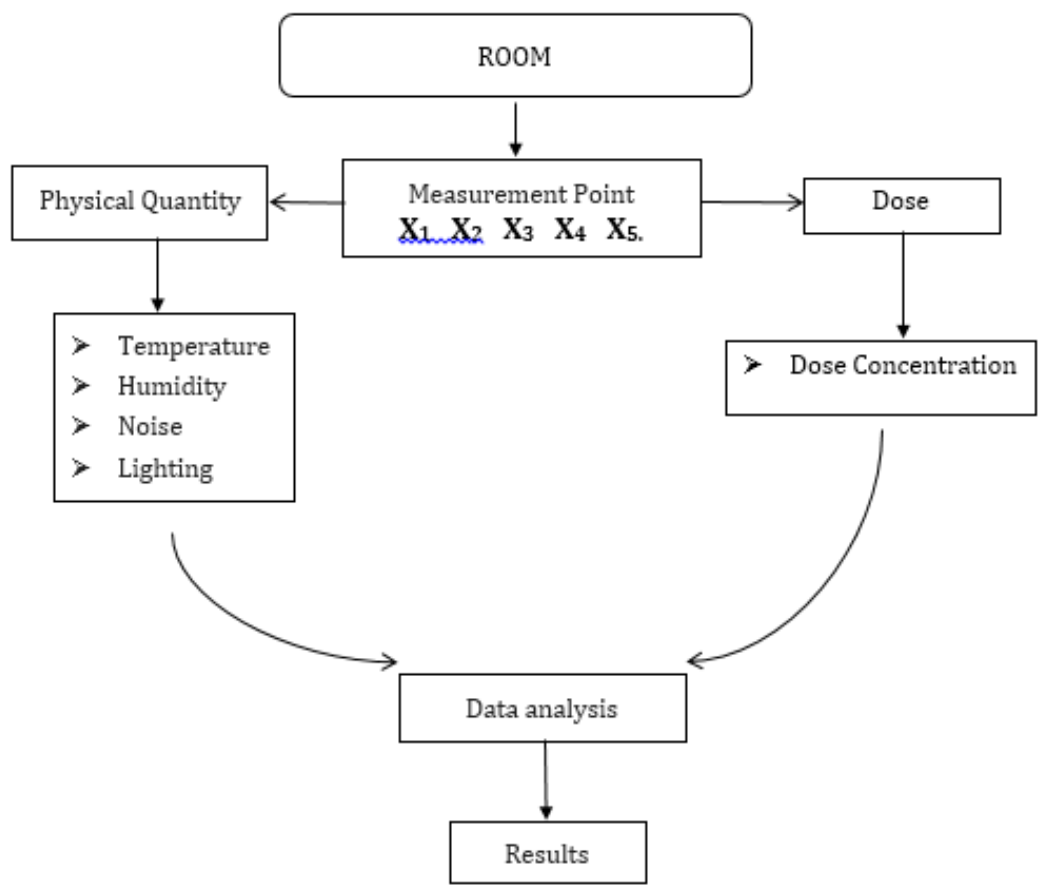

Figure 1. Research Block Diagram

\section{Results and Analysis}

Measurements were made in each room for each measurement point against physical stress (temperature, humidity, lighting, and noise) and the amount of radiation dose of radon gas contained in the room. Measurement of radiation dose (Du), was carried out on a survymeter $20 \mu \mathrm{Sv}$ measuring instrument and a calibration factor (fc) 0.986 . So that the actual radiation dose (Ds) can be determined with the following equation [8],

$$
D_{s}=D_{u} \times f_{k}
$$

Where $\mathrm{Du}$ is the radiation dose measured by survymeter, Ds is the actual radiation dose and $f c$ is the calibration factor of the measuring instrument. The results of measurements of physical quantities and radiation dose of radon gas actually can be successively represented as shown in Figures 2, 3, 4, 5 and 6 as follows.

Ratnawati, I. G. A. A., Sutapa, G. N., \& Ratini, N. N. (2018). The concentration of radon gas in air-conditioned indoor. International Journal of Physical Sciences and Engineering, 2(2), 111-119. 


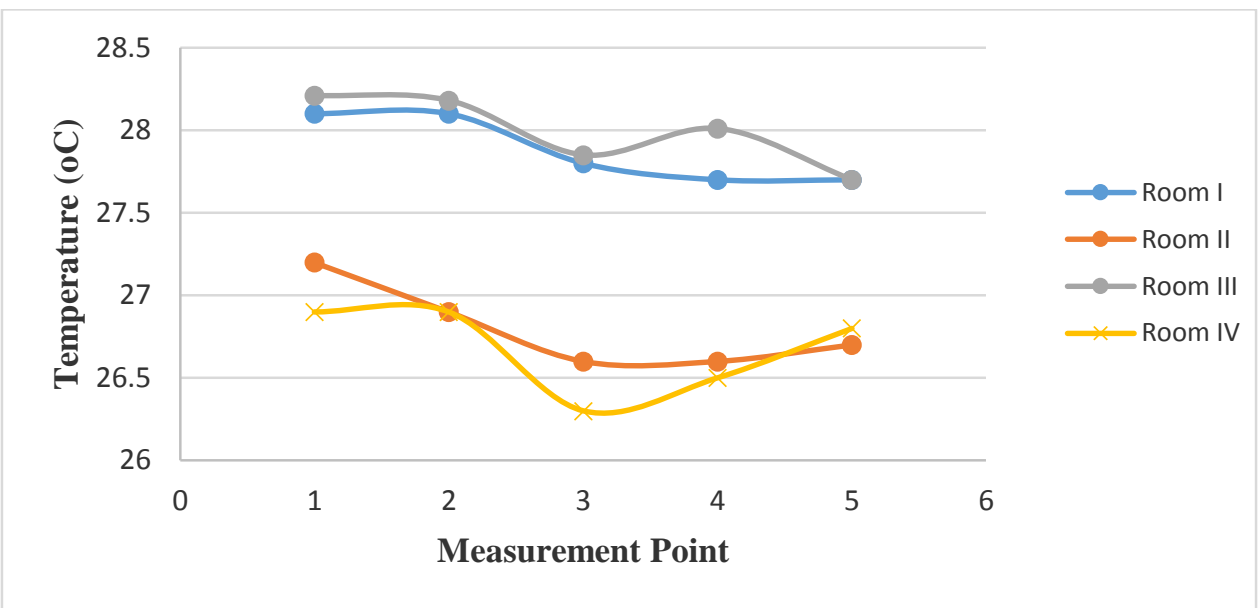

Figure 2. Graph of air temperature in the room

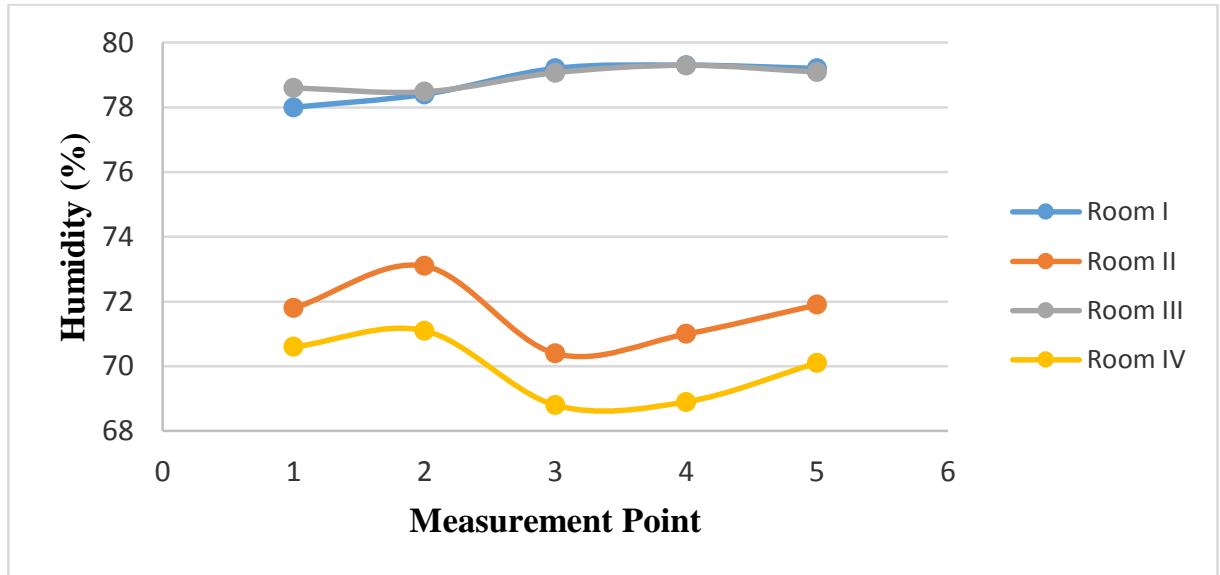

Figure 3. Graph of humidity in the room

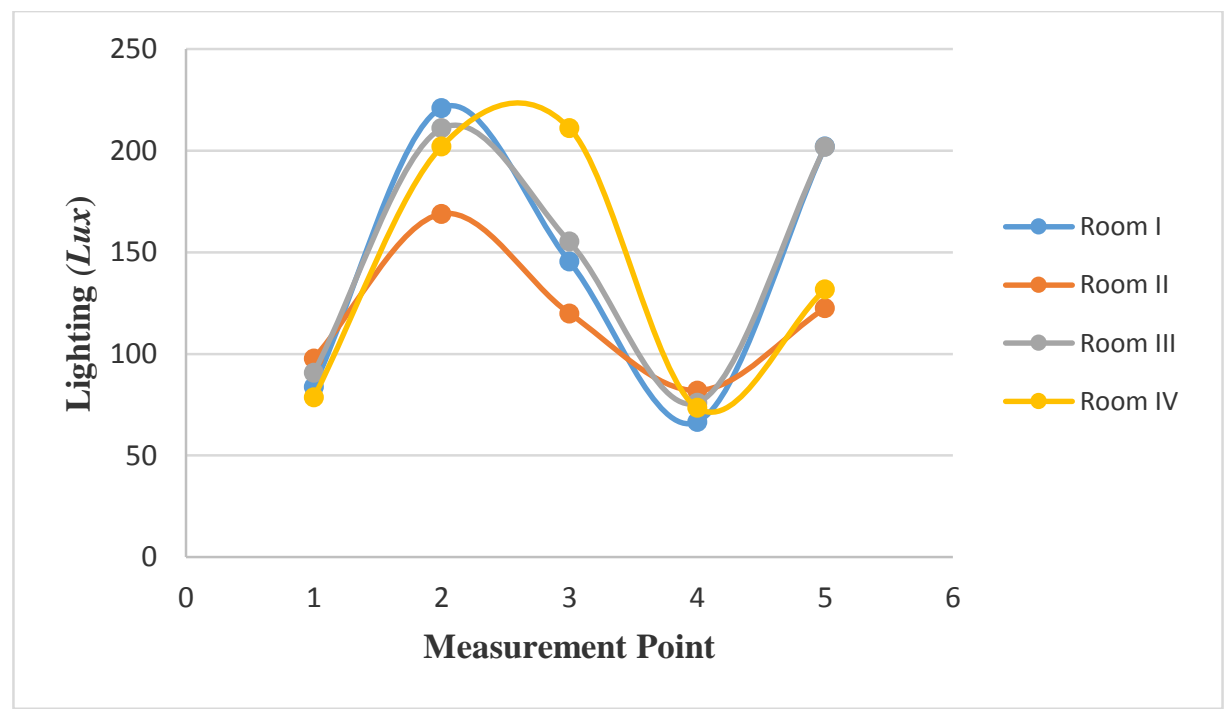

Figure 4. Graphical lighting in the room 


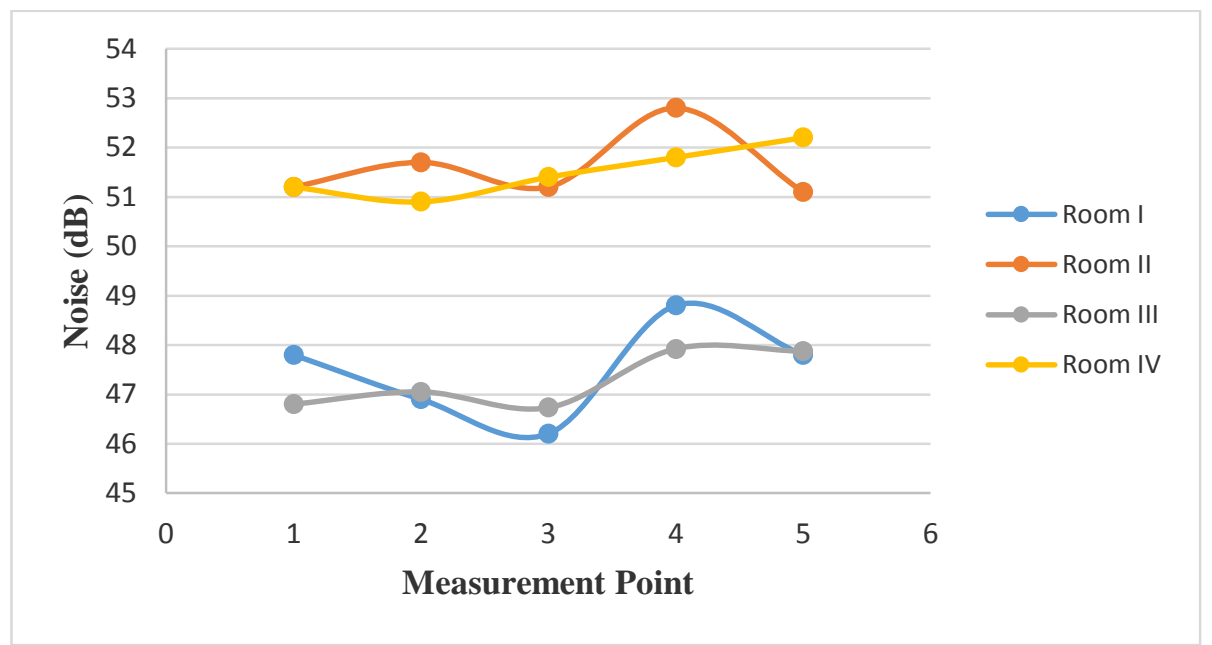

Figure 5. Graph of noise in the room

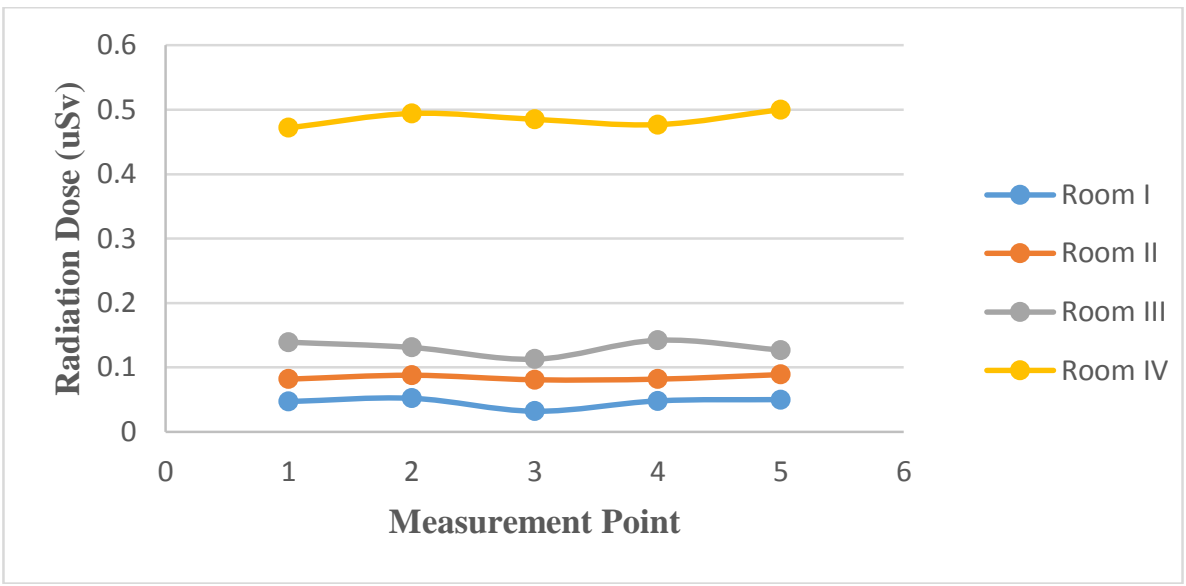

Figure 6. Graph of radiation dose of radon gas in the room

Based on the Decree of the Minister of Health of the Republic of Indonesia No. 1405/Menkes/SK/XI/2002 concerning health requirements for office work environment which includes temperature, humidity, lighting, and noise determined as shown in Table 1.

Table1

Physical size and health requirements of office work environments

\begin{tabular}{|c|c|c|}
\hline Physical Quantity & Health Requirements & Information \\
\hline Temperature & $18-28^{\circ} \mathrm{C}$ & $\begin{array}{l}\text { Space air conditioning is an effort made so that the } \\
\text { temperature in the workspace meets health } \\
\text { requirements. }\end{array}$ \\
\hline Humidity & $40-60 \%$ & $\begin{array}{l}\text { Space air conditioning is an effort made so that } \\
\text { humidity in the workspace meets health requirements. }\end{array}$ \\
\hline Noise & Min 100 Lux & $\begin{array}{l}\text { Lighting is the amount of irradiation in a field of work } \\
\text { needed to carry out activities effectively. }\end{array}$ \\
\hline Lighting & Max $85 \mathrm{~dB}$ & $\begin{array}{l}\text { Noise is the occurrence of unwanted sounds that } \\
\text { disturb or endanger the health }\end{array}$ \\
\hline
\end{tabular}

Ratnawati, I. G. A. A., Sutapa, G. N., \& Ratini, N. N. (2018). The concentration of radon gas in air-conditioned indoor. International Journal of Physical Sciences and Engineering, 2(2), 111-119. https://doi.org/10.29332/ijpse.v2n2.169 
In accordance with the health requirements of the office work environment as shown in Table 1. above, the temperature in all rooms averaged $26.68-27.99{ }^{\circ} \mathrm{C}$ is still fulfilled because it is still in the range $18-28{ }^{\circ} \mathrm{C}$. Average humidity is $69.90-78.90 \%$ not fulfilled, humidity in the room is too high where the maximum humidity limit of a room is $60 \%$ while the results of research on four rooms of minimum humidity have reached $70 \%$, so the humidity in each room has a level high humidity. This condition is very likely to occur because the research location is near the coast or lowland which allows having optimum humidity above 60 \%. According to Fardiaz in 1992 and Pudjiastuti in 1998 where high humidity dissolved chemical compounds and then became vapor and exposed to workers, so did low humidity caused discomfort to workers. The average lighting is $118.18-143.75$ Lux is the room lighting that is fulfilled according to the permitted limit where the lighting of a minimum room is 100 Lux. Average noise 47.27 - $51.60 \mathrm{~dB}$ still meets the standard maximum hearing threshold is $85 \mathrm{~dB}$ [7].

Besides the physical quantity that determines the air quality in the room is also determined by the radiation dose of radon gas that accumulates in the room. Of the four rooms that have different conditions, where the room using gypsum as a ceiling and air-conditioned material (room IV) was detected the highest radon gas radiation, which is an average of $0.468 \mu \mathrm{Sv}$ compared to room I, II, and III, respectively, radiation radon gas averaged only $0.0458,0.084$ and $0.134 \mu \mathrm{Sv}$. Likewise, what is shown in the reference graph in Figure 3.5 where rooms I, II, and III show the dose value is quite different from room IV. The room I and room III showed fluctuations in radiation doses at each measurement point, whereas in rooms II and IV there was almost no fluctuation in radiation doses or radiation doses accumulated evenly throughout the room. Dosage fluctuations do not occur in rooms II and IV due to air-conditioned rooms. Rooms with gypsum ceilings increase radiation doses and air-conditioned rooms can accumulate radiation doses evenly in the room. The results of this study support the recommendations published by UNSCEAR in 2000, which provide an overview that the levels of radon gas in the house are quite high, especially in closed rooms or inadequate ventilation, such as basements and enclosed spaces that use AC systems as coolers [7,9].

The dose of alpha radiation received by the respiratory tract that originates from a child decays radon about 20 times greater than that emitted by radon gas itself. As for the effects of radiation generated has a very large risk to the health of the respiratory tract, depending on the concentration of children decompose radon in the air and the physiological parameters of the respiratory system, for example, can cause asthma and lung cancer [11].

The ANOVA test results, the four rooms significantly $(p>0,000)$ showed that the quality of the room still fulfilled environmental health requirements for temperature, humidity, noise and radiation doses. Whereas for lighting physical properties in the four rooms was not significant $(\mathrm{p}<0.867)$ on the quality of the room. Statistical analysis of each physical quantity is 42,487 $>2,286$ for temperature, 175,053 $>2,286$ for humidity, $55,622>2,286$ for noise and 2390,133 > 2,86 for radiation dose shows that the Fcount $>$ F table, which means that the air quality in the room is still significant to thank you for environmental health. Likewise, the lighting in the room is not significantly fulfilled with a value of Fcount $<$ Ftable $(0.241<2,286)$.

\section{Conclusion}

After doing research on the physical quantity and concentration of radon gas on air quality in the room, it can be concluded that:

a) Air quality in terms of physical temperature, humidity, noise significantly still meets environmental health requirements according to the Minister of Health Decree No. 1405/Menkes/SK/XI/2002. But the lighting in the room has not been significantly fulfilled.

b) Rooms with gypsum ceilings increase radiation doses and air-conditioned rooms can accumulate radiation doses evenly in the room.

\section{Suggestion}

The room with gypsum and air-conditioned ceilings should have a vent that can be opened and closed. When the room is not occupied immediately the ventilation may be opened wide so that there is an exchange of air in the room and ensure regular air conditioning maintenance. 
Conflict of interest statement and funding sources

The authors declared that they have no competing interest. The study was financed by DIPA BLU, Udayana University.

Statement of authorship

The authors have a responsibility for the conception and design of the study. The authors have approved the final article.

Acknowledgments

Acknowledgments were conveyed to Udayana University through DIPA BLU which has funded the Leading Research Study Program (PUPS) in 2018.

Ratnawati, I. G. A. A., Sutapa, G. N., \& Ratini, N. N. (2018). The concentration of radon gas in air-conditioned indoor. International Journal of Physical Sciences and Engineering, 2(2), 111-119. https://doi.org/10.29332/ijpse.v2n2.169 


\section{References}

1. Akhadi, M. (2000). Dasar-dasar proteksi radiasi. Jakarta: Rineka Cipta, 41. View in (Google Scholar)

2. Bunawas. (2004). Current Status of Radon Exposure and Cancer Risk and Future Radiation Protection Efforts, Papers, Expert Researchers' Oration, Jakarta.

View in (Google Scholar)

3. Bunawas. (1993). Radon Measurement Status in Indonesia, Scientific Presentation for researchers (youngLIPI, PSPKR, Jakarta.

View in (Google Scholar)

4. Protection, R. (2003). the Management of Radioactive Waste in the Oil and Gas Industry. Safety Reports Series, 34.

View in (Google Scholar)

5. Lubin, J. H. (1994). Radon and lung cancer risk: a joint analysis of 11 underground miners studies (No. 94). US Dept. of Health and Human Services, Public Health Service, National Institutes of Health.

View in (Google Scholar)

6. National Research Council. (1999). Health effects of exposure to radon: BEIR VI (Vol. 6). National Academies Press.

View in (Google Scholar)

7. Singh, K., Singh, M., Singh, S., Sahota, H. S., \& Papp, Z. (2005). Variation of radon (222Rn) progeny concentrations in outdoor air as a function of time, temperature and relative humidity. Radiation measurements, 39(2), 213-217.

View in (Google Scholar)

8. Syarbaini, S., \& Bunawas, B. (2010). Studi Penurunan Konsentrasi Gas Radon Dalam Ruangan Menggunakan Beton Ringan. Jurnal Permukiman, 5(1), 1-6.

View in (Google Scholar)

9. Utami E. T. C. (2005). The Relationship Between Air Quality in Central Air-conditioned Rooms and Sick Building Syndrome in Telkom Div IV, Central Java, UNNES.

View in (Google Scholar)

10. United Nations. Scientific Committee on the Effects of Atomic Radiation. (2000). Sources and effects of ionizing radiation: sources (Vol. 1). United Nations Publications.

View in (Google Scholar)

11. Abdul-Wahab, S. A. (2011). Sick building syndrome. Springer-Verlag Berlin Heidelberg. View in (Google Scholar) 


\section{Biography of Authors}

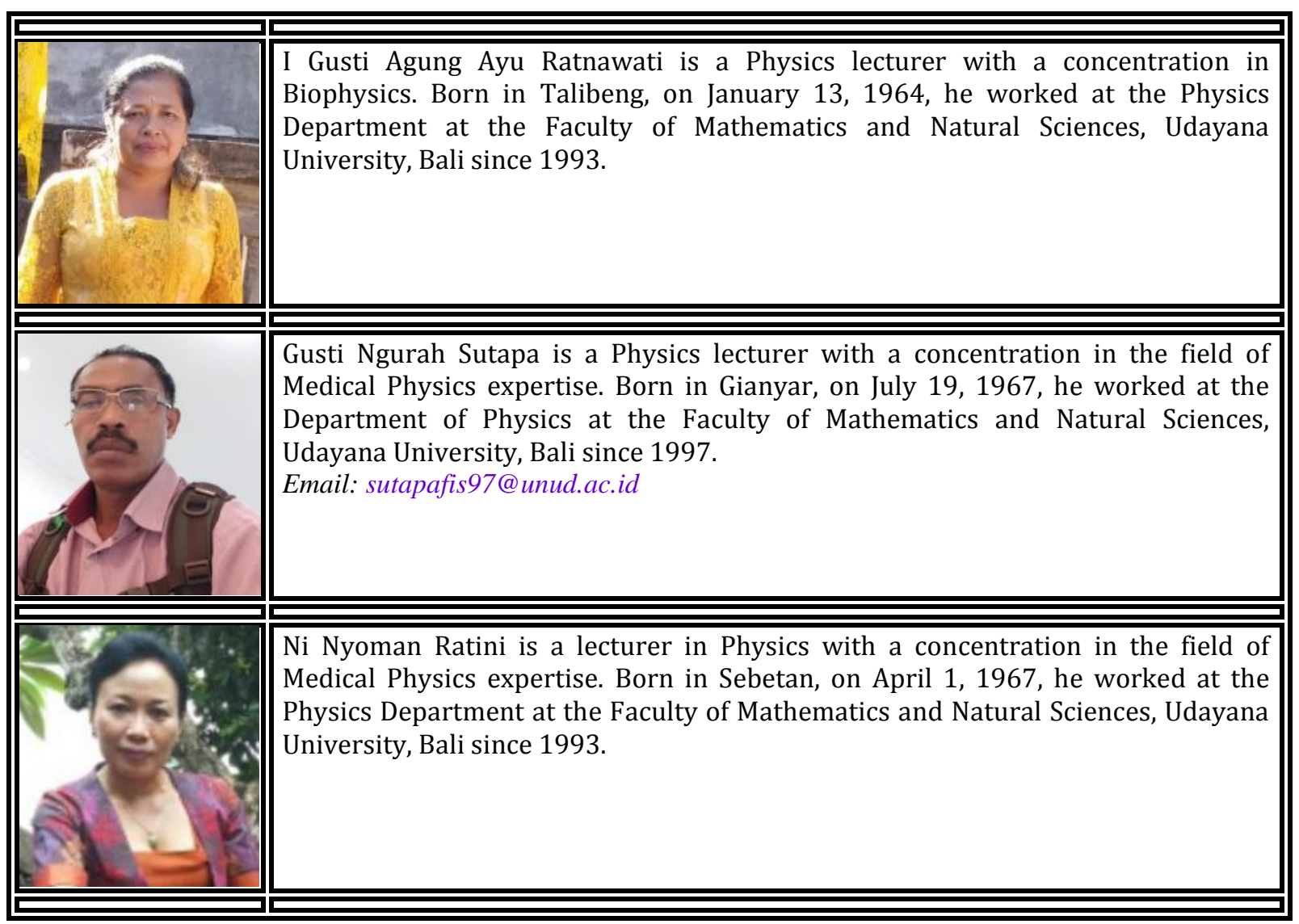

Ratnawati, I. G. A. A., Sutapa, G. N., \& Ratini, N. N. (2018). The concentration of radon gas in air-conditioned indoor. International Journal of Physical Sciences and Engineering, 2(2), 111-119. https://doi.org/10.29332/ijpse.v2n2.169 